\title{
Increasing the Motivation and Learning Outcomes of Students through the Application of the Problem Based Learning Model in Learning Physics
}

\author{
Desta Velly ${ }^{1^{*}}$ \\ ${ }^{1}$ Public Senior High School 12, Pekanbaru Riau, Indonesia.
}

DOI: $10.29303 /$ jossed.v2i1.719

\section{Article Info}

Received : March 25th, 2021

Revised : April 26th, 2021

Accepted: April 29th, 2021

\begin{abstract}
The results of the learning test show that almost more than half of the students have not been able to solve the questions well, so learning improvements or innovations are needed. Problem based learning is one of the recommended learning models in the implementation of the 2013 curriculum because this model is proven to be able to stimulate higher-order thinking skills by designing problems in real contexts. The purpose of this action research is to improve learning outcomes and student motivation in the application of the Problem Based Learning model in learning physics. The subjects of this study were students of class XI MIPA 2, Public Senior High School 12 Pekanbaru. This research is a classroom action research conducted in 2 cycles. The results of this study obtained test data on the learning outcomes of students in cycle I with absorption of $75.25 \%$, in cycle II absorption of $81.29 \%$, motivation of students in learning cycle I and cycle II in good categories.
\end{abstract}

Keywords: Physics learning outcomes; learning motivation; Problem Based Learning

Citation: Velly, D. (2021). Increasing the Motivation and Learning Outcomes of Students through the Application of the Problem Based Learning Model in Learning Physics. Journal of Science and Science Education, 2(1).52-57. doi:https://doi.org/10.29303/jossed.v2i1.719

\section{Introduction}

The knowledge that students get in learning physics in class is very limited. Sometimes it's time to work on old sample problems, because students aren't really working on them. The challenge now is how to motivate students to increase. Physics is a fun subject, so that students begin to accept physics as an interesting and not boring subject. But in reality, in the field, there are still many students learning to memorize concepts, noting what the teacher tells them.

The implementation of learning in class generally begins with material explanations, provides sample questions and continues with assignments. Students only listen, take notes and do what is ordered. Teachers need to expand knowledge by reasoning students' express opinions and find their own learning experiences. The main improvement in the quality of education is the increase in educators, namely teachers. This is in accordance with the opinion of Munib (2012) that the main factor for the success of Indonesian education is the teacher.

Problem based learning is one of the recommended learning models in the implementation of the 2013 curriculum because this model has been shown to be able to stimulate high-order thinking skills by designing problems in a real context. Rusman (2013) problem-based learning is an innovation in learning because in PBL the thinking ability of students is really optimized through a systematic group or team work 
process, so that students can empower, hone, test, and develop their thinking skills on an ongoing basis.

Suharto (2014) states that the definition of PBL as problem-based learning is a learning model designed so that students get important knowledge that makes them adept at solving problems, and has their own learning model and has the ability to participate in teams. Fatimah (2016) also states that the problembased learning model with cognitive conflict strategies affects students' critical thinking skills. It can be concluded that the problem-based learning model is designed so that students are proficient in solving problems and able to think critically.

Kamdi (2007) argues that the Problem Based Learning Model is defined as a learning model which involves students trying to solve problems through several stages of the scientific method so that students are expected to be able to learn knowledge related to these problems and at the same time students are expected to have skills in solving problems. PBL stages include: orientation of students to problems, organizing students, guiding individual and group investigations, developing and presenting work, and analyzing and evaluating the problem-solving process.

Motivation is an impulse that arises in a person, consciously or unconsciously to carry out an action with a specific goal or efforts that can cause a person (group) of certain people to be moved to do something to achieve the goal they want or get satisfaction with their actions (Uno, 2010). Armes \& Archer states that teachers can change and increase student motivation, with teachers taking certain actions in the classroom so as to generate interest, enthusiasm and motivation for student learning (Suciati, 2007).

The realm of motivation is very diverse, one of which is motivation in the realm of learning. Motivation is a force that can encourage student activities in carrying out activities in order to achieve goals (Majid, 2015). The existence of high motivation is expected to be able to move students to make learning a necessity for themselves. According to Uno's (2010) opinion, motivation has an important role in learning, as an amplifier in learning, and can determine persistence in learning. According to Sadirman's opinion (2011) learning motivation is the overall driving force within students that causes learning activities, which ensures the continuity of learning activities and which provides direction for learning activities, so that the goals desired by the learning subject can be achieved.

It can be concluded that in the learning process learning motivation is a driving force within students to achieve the desired learning objectives. In accordance with Ali's (2012) statement, that changes in behavior in the learning process are the result of deliberate interaction with the environment due to readiness, motivation, and achieved goals.

Learning outcomes are the most important part of learning. Nana Sudjana (2009) defines student learning outcomes as behavioral changes as a result of learning in a broader sense covering the cognitive, affective, and psychomotor fields.

Research by Rahayu, et al (2017) conducted at Public Senior High School 1 Mukomuko states that the problem-based learning model can increase student activity, motivation and learning outcomes. The formulation of the problems in this study are: (1) How to increase the learning motivation of students through the application of the Problem Based Learning model (2) How to increase the learning outcomes of students through the Problem Based Learning model in learning physics at Public Senior High School 12 Pekanbaru.

The purpose of this study was to (1) improve student learning outcomes (2) describe the motivation of class XI MIPA 2 students through the application of the Problem Based Learning model in physics learning at Public Senior High School 12 Pekanbaru.

\section{Method}

The research was conducted in class XI MIPA 2 Public Senior High School 12 Pekanbaru in the even semester of the 2019/2020 academic year. The number of students was 32 students consisting of 12 male students and 20 female students.

This type of research is a classroom action research. The action taken in this research is the application of the Problem Based Learning model in physics learning. The classroom action research procedure that will be carried out consists of planning, implementing the action, observing and reflectingevaluation. The steps in the research can be described as follows.

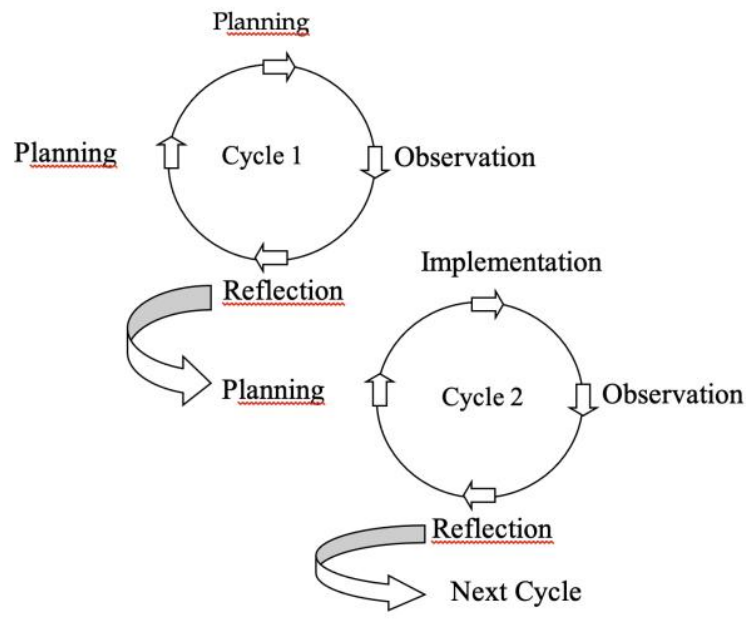

Figure 1: Classroom Action Research Flowchart with 4 Activity Stages (Sulipan; 2009). 
At the planning stage, the researcher prepared a research instrument consisting of learning tools and data collection instruments. The learning tools consist of a syllabus, a lesson plan, a list of problems, and a learning outcome test question sheet. The data collection instrument consisted of observation sheets of students' motivation and learning outcome test kits. The observations used in this study were the students' motivation observation sheets using the Likert scale. Student learning outcomes data using a class average value system from student learning outcomes tests for each cycle. Data processing in this study was carried out by giving scores on the results of the evaluation given to students and calculating the scores on the results of observations of students' motivation.

This research was conducted in 2 cycles to improve student motivation and learning outcomes through PBL learning. In the first cycle with the subject of mechanical wave characteristics, it is seen that the increase in motivation and student learning outcomes, if the indicators of success have not been achieved, the research is continued in the second cycle with the subject of walking waves and stationary waves.

Implementation of action is the implementation of planning activities carried out by researchers in an effort to improve or improve the quality of learning. The implementation of actions in cycle I is carried out in the learning process regularly according to the learning activities of each meeting in lesson plan 1 with the subject of the characteristics of mechanical waves, applying the PBL learning model.
While the implementation of the second cycle of action, based on the reflection planning cycle I using lesson plan 2 with the subject of walking waves and stationary waves. The actions taken are carried out in accordance with the steps of the PBL learning model. Observation is carried out simultaneously with the implementation of the action, the observation is carried out by the observer. This observation is carried out on student motivation during the learning process taking place at the same time and place. Observation aims to collect data about students' motivation during the learning process which will be used as reflection material.

Reflection is carried out after the action ends each cycle. At this stage the researcher examines, sees and considers the results or impact of the actions in the first cycle. If the location of the successes and obstacles of the first cycle is known, the researcher determines the design for the second cycle. After the second cycle ended, the researcher conveyed the suggested plan to other researchers with the notes they had. This reflection aims to improve and optimize the implementation of the next meeting actions.

\section{Result and Discussion}

Implementation and subject matter per cycle can be seen in full in Table 1.

Table 1. Subjects during the Research Class XI MIPA 2 Public Senior High School 12 Pekanbaru.

\begin{tabular}{|c|c|c|c|c|}
\hline Cycle & Meeting & Subject & Sub Subject & Time (minutes) \\
\hline Cycle I & 1 & $\begin{array}{l}\text { Characteristics of mechanical } \\
\text { waves }\end{array}$ & $\begin{array}{l}\text { Mechanical wave: characteristics } \\
\text { - Reflection } \\
\text { - Refraction }\end{array}$ & $2 \times 45^{\prime}$ \\
\hline & 2 & & $\begin{array}{l}\text { - Diffraction } \\
\text { - Interferention }\end{array}$ & $2 \times 45^{\prime}$ \\
\hline \multirow[t]{2}{*}{ Cycle II } & 1 & $\begin{array}{l}\text { Moving wave and stationary } \\
\text { wave }\end{array}$ & $\begin{array}{l}\text { Motion wave and Stationary wave: } \\
\text { - the wave equation }\end{array}$ & $2 \times 45^{\prime}$ \\
\hline & 2 & & Physical Quantities & $2 \times 45^{\prime}$ \\
\hline
\end{tabular}

\section{First Cycle}

At the planning stage, learning tools and instruments and observation sheets were prepared. There is only one observer needed to observe the learning process, namely peers. Before the learning takes place, the observer is given directions for filling out the observation sheet. Planning in cycle 1 was carried out in two meetings and one daily test with the material characteristics of mechanical waves.

The implementation stage of the learning process action is carried out based on the learning implementation plan (RPP) that has been prepared. The lesson plan used in the action is divided into 3 stages, namely: initial activities, core activities and closing activities. The action taken in this study is the application of the Problem Based Learning model in physics learning. Each learning meeting is carried out in accordance with the PBL stages which include: student orientation to problems, organizing students, guiding individual and group investigations, developing and presenting work, and analyzing and evaluating the problem-solving process. At the end of the cycle a daily test and reflection were carried out.

The observation stage is carried out at the time of implementing the learning process action. Researchers 
act as teachers, peers as observers. Each meeting carried out the observations that were observed consisting of: the persistence of students in doing the given assignment, asking questions about material that did not understand, expressing opinions according to active material discussing in groups, being willing to present work results in front of the class, happy to find and solve problems question. The purpose of observation is to find out and also obtain an objective picture of the development of the process and the effect of the selected action on the learning carried out by the teacher.

In the reflection stage, it is carried out to examine the actions that have been carried out, whether they are in accordance with the planning and the expected results. And to see the weaknesses that occur in cycle I so that they can be fixed in the next cycle.

The conclusion from the results of the reflection there are still several aspects in the learning process that must be improved, namely: The problems given must be closer to real life, so that students are more motivated. The teacher gives more challenging questions that lead to the preparation of problem solving. Controlling students who do not work in their groups. Provide a variety of examples at the time of providing reinforcement.

Based on the conclusion from the reflection in cycle I which still has many weaknesses and shortcomings as described, the researchers improved the learning process in cycle II.

\section{Second Cycle}

The planning stage was prepared learning tools and instruments, motivation questionnaires and observation sheets, as well as correcting the deficiencies in cycle 1 reflection. Planning in cycle II was carried out in two meetings and one daily assessment with the material of walking waves and stationary waves.

The implementation and observation stages in cycle 2, fix the deficiencies that occur in cycle I. Based on the results of reflection in cycle I, the learning process is improved by providing learning: problems are closer to real life, asking challenging questions, controlling students better, and providing examples vary.

Learning activities that have been carried out in cycle II are reflected by the researcher. Based on the analysis of the data obtained from the observation sheet while applying the Problem Based Learning model in the second cycle, it was seen that the motivation of students was getting better. The implementation of the learning process action is in accordance with the planner, it can be seen from the results of observations at each meeting.
The results of observing the average motivation of students during learning activities in both cycles can be seen in Table 2 .

Table 2. Average Percentage of Students' Motivation in Each Cycle.

\begin{tabular}{lll}
\hline Observed aspects & \multicolumn{2}{l}{ Average (\%) } \\
& Cycle 1 & Cycle 2 \\
\hline $\begin{array}{l}\text { Persistence of students in doing } \\
\text { the assigned task }\end{array}$ & 64.1 & 70.4 \\
$\begin{array}{l}\text { Ask about material that you don't } \\
\text { understand }\end{array}$ & 45.4 & 54.7 \\
$\begin{array}{l}\text { Express opinions according to the } \\
\text { material }\end{array}$ & 59.4 & 61.0 \\
$\begin{array}{l}\text { Active discussion in groups } \\
\begin{array}{l}\text { To present work results in front of } \\
\text { the class }\end{array}\end{array}$ & 67.1 & 78.1 \\
$\begin{array}{l}\text { Enjoy finding and solving } \\
\text { problems }\end{array}$ & 61.0 & 70.4 \\
Average & 60.2 & 66.7 \\
\hline
\end{tabular}

Table 2 shows the average percentage of students' motivation in each cycle increased from $60.2 \%$ to $66.7 \%$ in the good category. This means that the application of the Problem Based Learning model during the learning process can increase the motivation of students.

The results of the learning test were obtained from the students' scores after taking the daily assessment tests. Analysis of the results of student learning tests for each cycle can be seen in Table 3.

Table 3. Students' Physics Learning Outcomes with the Implementation of PBL.

\begin{tabular}{llccl}
\hline $\begin{array}{l}\text { Daily } \\
\text { Rating Test } \\
\text { Score }\end{array}$ & Predikat & $\begin{array}{c}\text { Cycle } 1 \\
(\%)\end{array}$ & $\begin{array}{c}\text { Cycle } 2 \\
(\%)\end{array}$ & Describe \\
\hline $93-100$ & A & 65.63 & 78.13 & Completed \\
$84-92$ & B & & & Not \\
$75-83$ & C & 34.37 & 21.87 & $\begin{array}{l}\text { Completed } \\
<75\end{array}$ \\
\hline
\end{tabular}

Daily assessment tests to determine student learning outcomes are given after the application of the Problem Based Learning model. The specified KKM is 75. The table above shows that the achievement of student learning outcomes who reach the KKM each cycle increases, with the percentage of completeness from $65.63 \%$ to $78.13 \%$. According to Sudarman (2012) that the Problem Based Learning model can improve students' analytical skills.

This study was declared successful if the average results of the observations indicated that the increase in learning motivation to apply the PBL learning model was in a good category, and $75 \%$ of students achieved the minimum completeness criteria on the final result test. Based on the conclusion from the reflection in 
cycle II that has improved learning from cycle I and is in accordance with the plan, the researcher made a decision until cycle II.

\section{Increased Learning Motivation}

This research emphasizes on improving classroom action which will affect the motivation and learning outcomes of students in the classroom. In cycle I, learning was carried out with the material characteristic of mechanical waves, students' learning motivation was still low, namely $60.2 \%$. The learning motivation of students has shown a positive increase in the good category.

In cycle II students' learning motivation had increased, the average learning motivation of students was $66.7 \%$. Good category. This result shows that learning using the PBL learning model can increase the learning motivation of students. The teacher's actions are as expected so that it has a good impact on the learning motivation of students. The importance of learning motivation for students is described by Slameto (2010), that the role of the teacher as a motivator can arouse and direct student behavior so that there are a number of behaviors that the teacher wants displayed by students.

\section{Improved Learning Outcomes}

Learning outcomes of students, in cycle 1, students who completed as many as 21 people from 32 people. The average student learning outcomes were 75.25 with the percentage of students who completed $65.6 \%$. This shows that in cycle 1 learning has not gone well, it still needs improvement to improve student learning outcomes. The results of reflection show that further learning is needed to improve student learning outcomes.

Learning outcomes of students, in cycle 2, students who completed as many as 23 people from 32 people. The average student learning outcomes are 81.29 with the percentage of students who have completed $78.1 \%$. This shows that learning through the application of the PBL model can improve student learning outcomes. According to Susilawati (2017), this result can occur because basically problem-based learning is a constructivist-based learning model, thus helping in maturing the concepts they have.

\section{Conclusion}

The learning process by applying the Problem Based Learning (PBL) model can improve student learning outcomes and student activities. The problems given in the learning process, by using the Problem Based Learning model, prefer real events or situations in student life. So that students understand the problems given. For further researchers, the application of the Problem Based Learning model cannot be used for all materials, it is recommended only for material that discusses actual problems that occur in student life.

\section{Acknowledgements}

Thanks to the principal of Public Senior High School 12 Pekan Baru and the Physics teachers who have allowed the author to research and assist in this research process.

\section{References}

Ali, M. (2012). Guru dalam Proses Belajar Mengajar. Bandung: Sinar Baru [Indonesian]

Fatimah, N., Gunawan, G., \& Wahyudi, W. (2017). Pembelajaran Berbasis Masalah Dengan Strategi Konflik Kognitif Terhadap Konsep Dan Kemampuan Berpikir Kritis Fisika Siswa Kelas XI SMKN 1 Lingsar Tahun Pelajaran 2015/2016. Jurnal Pendidikan Fisika Teknologi, 2(4), 183-190, doi: 10.29303/jpft.v2i4.423 [Indonesian]

Uno, H.B. (2010). Teori Motivasi dan Pengukurannya. Jakarta: Bumi Aksara [Indonesian]

Kamdi, W. (2017). Model-model Pembelajaran Inovatif. Universitas Negeri Malang. Malang [Indonesian]

Sudarman, I. (2013). Penerapan Model Pembelajaran Berbasis Masalah (Problem-Based Learning) untuk Meningkatkan Aktivitas Dan Hasil Belajar Siswa Pada Mata Pelajaran Ekonomi Siswa Kelas X1 SMA Negeri 1 Sawan Tahun 2012/2013. Jurnal Pendidikan Ekonomi Undiksha, 2(1). doi:http://dx.doi.org/10.23887/iipe.v2i1.807. [Indonesian]

Rusman. (2013). Model-Model Pembelajaran, PT Raja Grapindo Persada, Jakarta. [Indonesian]

Majid, A. (2015). Strategi Pembelajaran, Bandung: Remaja Rosdakarya. [Indonesian]

Munib, A. (2012). Pengantar Ilmu Pendidikan, Semarang UPT Unnes Press. [Indonesian]

Rahayu, A.S., Sakti, I., \& Putri, D.H. (2017). Penerapan Model Pembelajaran Berbasis Masalah (Problem) dengan Pendekatan Saintifik untuk Meningkatkan Aktivitas Belajar, Hasil Belajar Fisika dan Motivasi Belajar Siswa SMAN 01 Mukomuko. Jurnal Pembelajaran Fisika. 1(1), 19-27 [Indonesian]

Rusman. (2013). Model-Model Pembelajaran. Jakarta: PT Raja Grapindo Persada. [Indonesian]

Slameto. (2010). Belajar dan Faktor-faktor yang Mempengaruhinya. Jakarta: Rineka Cipta. [Indonesian] 
Sardiman. (2011). Interaksi dan Motivasi Belajar Mengajar. Jakarta: PT Raja Grafindo Persada. [Indonesian]

Suciati. (2007). Materi pokok belajar dan pembelajaran. Jakarta: Universitas Terbuka. [Indonesian]

Suharto. (2014). Peningkatan Hasil dan Aktivitas Belajar IPS Melalui Model Problem-Based Leaning Berbantuan Media di SMP Negeri 2 Kawunganten Cilacap. Tesis. Program Pascasarjana, Universitas Negeri Yogyakarta. [Indonesian]

Sulipan. (2009). Penelitian Tindakan Kelas. Bandung: Widyaiswara. [Indonesian]

Susilawati, S., Jamaluddin, J., Bachtiar, I. (2017). Pengaruh Model Pembelajaran Berbasis Masalah (PBM) Berbantuan Multimedia terhadap Kemampuan Berpikir Kritis Peserta Didik Kelas VII SMP Negeri 2 Mataram Ditinjau dari Kemampuan Akademik. Jurnal Pijar Mipa, 12(2), 64-70, doi: 10.29303/jpm.v12i2.343. [Indonesian] 